\title{
Biofortification of cowpea beans with iron: iron's influence on mineral content and yield
}

\author{
C. Márquez-Quiroz ${ }^{1}$, E. De-la-Cruz-Lázaro ${ }^{1 *}$, R. Osorio-Osorio ${ }^{1}$, and E. Sánchez-Chávez² \\ ${ }^{1}$ Juárez Autonomous University of Tabasco, Academic Division of Agricultural Science. Villahermosa, Ta- \\ basco, Postal Code 86280, Mexico. ${ }^{2}$ Research Center for Food and Development. Vencedores del Desierto, \\ Delicias City, Chihuahua, Postal Code 33089, Mexico. *Corresponding author: efrain.delacruz@ujat.mx
}

\begin{abstract}
Iron $(\mathrm{Fe})$ deficiency is the most prevalent nutrient deficiency worldwide. Agronomic biofortification is an agricultural strategy for improving the micronutrient concentrations in staple food plants. At present, fertilization is a major vehicle for changing plant mineral contents and food quality. A greenhouse study was conducted to assess the effects of iron chelate and ferrous sulfate applications on the biofortification of Fe and its impacts on the mineral content and yield of cowpea beans. Four application rates of both forms were tested $(0,25,50$, and $100 \mu \mathrm{M} \mathrm{L}^{-1}$ ) for $40 \mathrm{~d}$. The amount and type of Fe application affected the mineral seed content, yield and yield components. Applying of $\mathrm{Fe}$ in the form of ferrous sulfate at $25 \mu \mathrm{M} \mathrm{L}^{-1}$ was found to be the optimal rate for biofortifying the cowpea bean plant, because it favored the seed yield and increased the bioavailable Fe content in the seeds over that of the control. The best iron chelate rate was $100 \mu \mathrm{M} \mathrm{L}^{-1}$. Thus, it was considered feasible to implement an Fe fertilization program to improve the nutritional quality of cowpea bean crops by increasing the $\mathrm{Fe}$ concentrates in the seeds.
\end{abstract}

Keywords: Vigna unguiculata, iron chelate, minerals, ferrous sulfate

\section{Introduction}

Grain legumes (also known as pulses) occupy an important place in global food and nutrition, and they are an important constituent of the diets of a very large number of people. Legumes are rich not only in proteins but also in other nutrients such as starch, oil, vitamin, and minerals (Katoch, 2013). Most of the nutritional requirements of the rural population are still met by legumes, which constitute an important source of protein.
The cowpea bean (Vigna unguiculata [L.] Walp) is a dicotyledonous plant belonging to the order Fabales, family Fabaceae, Faboideae, Phaseoleae tribe, subtribe Phaseolinea, and genus Vigna. It is used in different parts of the world in traditional and cultural practices and, therefore, its cultivation is restricted to specialized geographical pockets in different agroecological regions, primarily by poor farming communities that derive their sustenance and livelihood 
from such crops (Carvalho et al., 2012). As a result, the cowpea is commonly referred to as 'poor man's meat', particularly among the inhabitants of rural areas and urban slums in Tabasco, Mexico. The grains are processed into different types of food products such as tamalitos, bean tortillas, and soup. Green, immature cowpea pods are harvested and sold in local markets for consumption as a vegetable.

Iron $(\mathrm{Fe})$ is an essential micronutrient for plants and for humans, and it is a constituent of a number of important macromolecules, including those involved in respiration, photosynthesis, DNA synthesis, and metabolism (Briat, 2011). Plants obtain Fe from the soil, where Fe exists in either the ferrous $\left(\mathrm{Fe}^{2+}\right)$ or ferric $\left(\mathrm{Fe}^{3+}\right)$ ionic state. Although $\mathrm{Fe}$ is the fourth most abundant element in the earth's crust, it is poorly bioavailable in soil because it binds rapidly to soil particles and forms insoluble complexes under aerobic conditions at a neutral or alkaline pH (Gómez-Galera et al., 2010). There are estimates that some 3 billion people worldwide are afflicted by Fe deficiency; this deficiency is known to be particularly common in populations that depend on staple crops as the primary food and have little or no access to animal products (White and Broadley, 2005).

Agronomic biofortification is defined as the process of increasing the concentrations of essential elements in the edible portions of staple food plants through soil application, foliar application, by adding the elements to irrigation water (fertilization) or genetic improvement. This strategy was developed as a foodbased method to address widespread deficiencies in $\mathrm{Fe}$ and $\mathrm{Zn}$ that remain prevalent to the greatest extent in low income countries (Sadeghzadeh and Rengel, 2013; Mao et al., 2014). Micronutrient malnutrition, which is also known as "hidden hunger", is a major public health issue in most parts of the world and affects more than two billion people (Welch and Graham, 2004). More than $60 \%$ of the world's population is Fe deficient (Amarakoon et al., 2012).
Research to develop biofortified foods is ongoing and has largely focused on increasing the Fe content of the world's most important staple food crops including maize [Zea mays (L.)] (Ortega-Blu and Molina-Roco, 2007), wheat [Triticum sativum (L.)] (Aciksoz et al., 2011), common beans [Phaseolus vulgaris (L.)] (Blair, 2013), barley [Hordeum vulgare (L.)], and jerry oats [Avena sativa (L.)] (Bilski et al., 2012) because of the high prevalence of deficiencies associated with this micronutrient in the developing world. Therefore, the aim of the experiment was to assess the effects of iron chelate and ferrous sulfate applications on Fe biofortification and to understand its impacts on the mineral content and yield of cowpea beans under greenhouse pot conditions.

\section{Materials and Methods}

\subsection{Crop design and plant sampling}

The pot experiment was conducted at the Academic Division of Agricultural Science of Juárez Autonomous University of Tabasco from October 2013 to January 2014. The black plastic pots used in the experiment were 30.0 $\mathrm{cm}$ in height, and $30.0 \mathrm{~cm}$ in diameter, and they were filled with an inert substrate (Tepetzil). Cowpea bean [Vigna unguiculata (L.) Walp 'De Castilla'] seeds were germinated and grown under greenhouse conditions (26$34{ }^{\circ} \mathrm{C}, 86-94 \%$ relative humidity) at a density of 44,444 plants per hectare. Throughout the growing cycle, each pot received $1 \mathrm{~L}$ of nutrition solution. During the first $20 \mathrm{~d}$ after sowing, the seedlings were kept in nutrient solution that was diluted to $20 \%$ of the original solution, which was prepared on the basis of a Hoagland and Arnon (1950) solution with $14 \mathrm{mM} \mathrm{NO}_{3}^{-}, 1 \mathrm{mM} \mathrm{H}_{2} \mathrm{PO}_{4^{-}}, 2 \mathrm{mM}$ $\mathrm{SO}_{4}^{2-}, 6 \mathrm{mM} \mathrm{K}^{+}, 4 \mathrm{mM} \mathrm{Ca}^{2+}$, and $2 \mathrm{mM} \mathrm{Mg}^{2+}$, and then modified to fit the $\mathrm{Fe}$ rates of the experiment. The solution was replaced every $3 \mathrm{~d}$. The micronutrients in the nutrient solution were supplied with a commercial soluble trace elements mix (Tradecorp AZ). The $\mathrm{pH}$ value of the 
nutrient solution was maintained at 5.5 and the electrical conductivity was adjusted to $2.0 \mathrm{dS} \cdot \mathrm{m}^{-1}$. The irrigation water was classified as having a low salinity and a low sodium content (C1S1); E.C: $1.3 \mathrm{dS} \mathrm{m}^{-1}$, pH: 7.0; cations $\left(\mathrm{mML}^{-1}\right): \mathrm{Ca}^{2+}=4.6, \mathrm{Mg}^{2+}=1.3, \mathrm{~K}^{+}=0.2, \mathrm{Na}^{+}=3.0$ and anions $\left(\mathrm{mM} \mathrm{L}^{-1}\right): \mathrm{HCO}^{3-}=4.6, \mathrm{Cl}^{-}=4.0$, and $\mathrm{SO}_{4}^{2-}=0.0$. Four Fe rates $\left(0,25,50\right.$, and $\left.100 \mu \mathrm{M} \mathrm{L}^{-1}\right)$ were tested in a completely randomized experimental design with six replications. Ferrous sulfate $\left(\mathrm{FeSO}_{4} \cdot 7 \mathrm{H}_{2} \mathrm{O}\right)$ and iron chelate (Fe-EDDHA) were used as Fe sources, and they were added to the nutrient solution for 70 days beginning at 20 days after sowing.

\subsection{Determining mineral nutrients}

The seed material was thoroughly cleaned and ground in a Willey mill to pass through a 2-mm mesh and stored in airtight bags for further analysis. Following Wolf (1982), the N, P, K, Ca, Mg, Fe, Mn, Zn, and $\mathrm{Cu}$ were mineralized by wet digestion. For this process, $0.2 \mathrm{~g}$ of dry cowpea beans was ground and mineralized with $12 \mathrm{H}_{2} \mathrm{SO}_{4}$ and $30 \% \mathrm{H}_{2} \mathrm{O}_{2}$, with free $\mathrm{P}$, at a temperature from $275^{\circ} \mathrm{C}$ to $300^{\circ} \mathrm{C}$. Following the resulting mineralization, and after the addition of $20 \mathrm{~mL}$ of deionized $\mathrm{H}_{2} \mathrm{O}$, the mineral nutrients were determined as describe above.

The total $\mathrm{N}$ concentration and total crude protein content $(\mathrm{N} \times 6.25)$ were determined by using the standard micro-Kjeldahl method (AOAC, 2002). The total $\mathrm{P}$ concentration was determined by using the colorimetric nitrovanadomolybdate method, and the total K concentration was analyzed by flame photometry (Alcántar and Sandoval, 1999). The total $\mathrm{Mg}$ and $\mathrm{Ca}$ concentrations were quantified by atomic absorption spectrophotometry, as were the micronutrients $\mathrm{Fe}, \mathrm{Cu}, \mathrm{Mn}$, and $\mathrm{Zn}$. All measurements were run in triplicate.

\subsection{The physical characteristics of the seeds and their yields}

The axial dimensions of length, width, and thickness for 25 whole healthy seeds were measured with a digital slide caliper with an accuracy of $0.01 \mathrm{~mm}$ (Mitutoyo). One hundred seeds from each treatment were weighed separately by using a digital electronic balance with an accuracy of $0.01 \mathrm{~g}$ (Sartorius 6124), and the total weight was recorded as the 100 -seed weight. The plants were harvested 90 days after sowing, and the yield was expressed as the mean seed weight per plant. The collected cowpea beans were weighed on each plant at sampling. The seed yield was computed to have a $13 \%$ moisture content.

\subsection{Statistical methods}

The statistical significance for each treatment was assessed by using an orthogonal contrast test provided by the statistical package SAS 9.2 for Windows (SAS Institute, 2009).

\section{Results and Discussion}

\subsection{Mineral content}

Plants are the principal source of minerals for most of the Earth's population. In the present study, the highest crude protein and $\mathrm{N}$ contents were found in plants treated with $50 \mu \mathrm{M} \mathrm{L}^{-1}$ ferrous sulfate and 100 $\mu \mathrm{M} \mathrm{L}^{-1}$ iron chelate with an increase of $5.0 \%$ and $3.6 \%$, respectively, over the control (Figure 1A-1B). These values are frequently reported in the literature for cowpea bean seeds, and they range from $16.4 \%$ to $29.0 \%$ and $2.6 \%$ to $4.6 \%$, respectively (Carvalho et al., 2012). In comparison with the control, the $\mathrm{P}$ content increased by $12.9 \%$ and $23.3 \%$ in plants 
treated with $50 \mu \mathrm{M} \mathrm{L}^{-1}$ ferrous sulfate and $50 \mu \mathrm{M} \mathrm{L}^{-1}$ iron chelate (Figure 1C), respectively, whereas the $\mathrm{K}$ content declined by $10.07 \%$ and $12.9 \%$ with 25 and $100 \mu \mathrm{M} \mathrm{L}^{-1}$ ferrous sulfate, respectively, and $11.1 \%$, $17.7 \%$, and $10.3 \%$ with 25,50 , and $100 \mu \mathrm{M} \mathrm{L}^{-1}$ iron chelate, respectively (Figure 1D). However, the Ca and $\mathrm{Mg}$ contents increased by $28.5 \%$ and $8.8 \%$, re- spectively over the control, with $25 \mu \mathrm{M} \cdot \mathrm{L}-1$ ferrous sulfate (Figure 1E), and $25.0 \%$ and $13.6 \%$, respectively, with $50 \mu \mathrm{M} \mathrm{L}^{-1}$ iron chelate (Figure $1 \mathrm{~F}$ ). In this sense, low seed concentrations of $\mathrm{N}, \mathrm{P}, \mathrm{K}, \mathrm{Mg}$, $\mathrm{Ca}$ and $\mathrm{S}$ affect the levels of protein, fats, vitamins, antinutrientes, and other factors, in seeds (Welch and Graham, 2005).
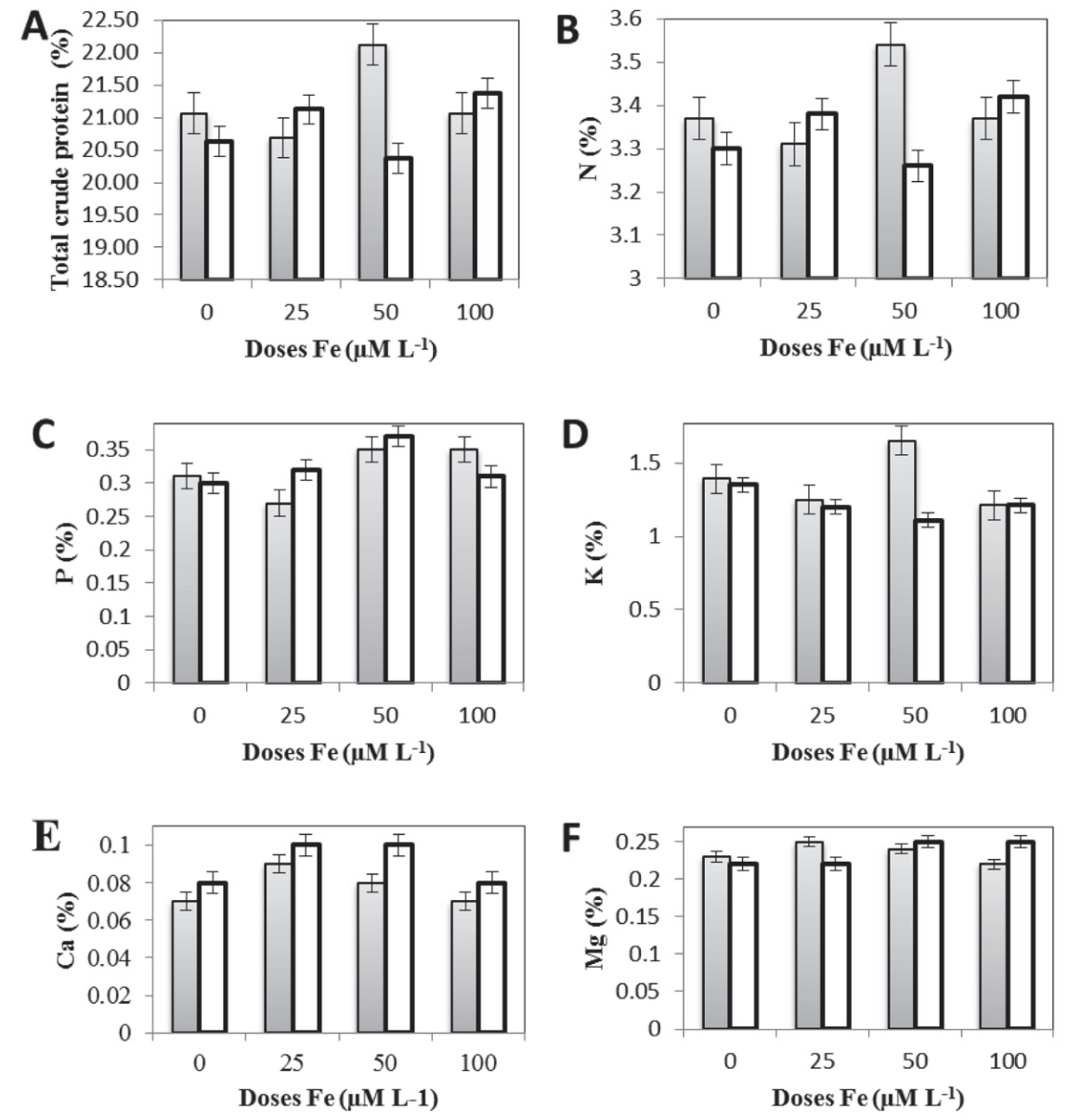

口Ferrous sulfate

DIron chelate

Figure 1. The total crude protein (A), nitrogen (B), phosphorus (C), potassium (D), calcium (E) and magnesium (F) contents in the seeds of the cowpea bean cultivar De Castilla in response to different application rates of ferrous sulfate and iron chelate. The data are \pm the standard error $(n=4)$ and are significantly different from the initial values at $P<0.001$ based on the orthogonal contrast test. 

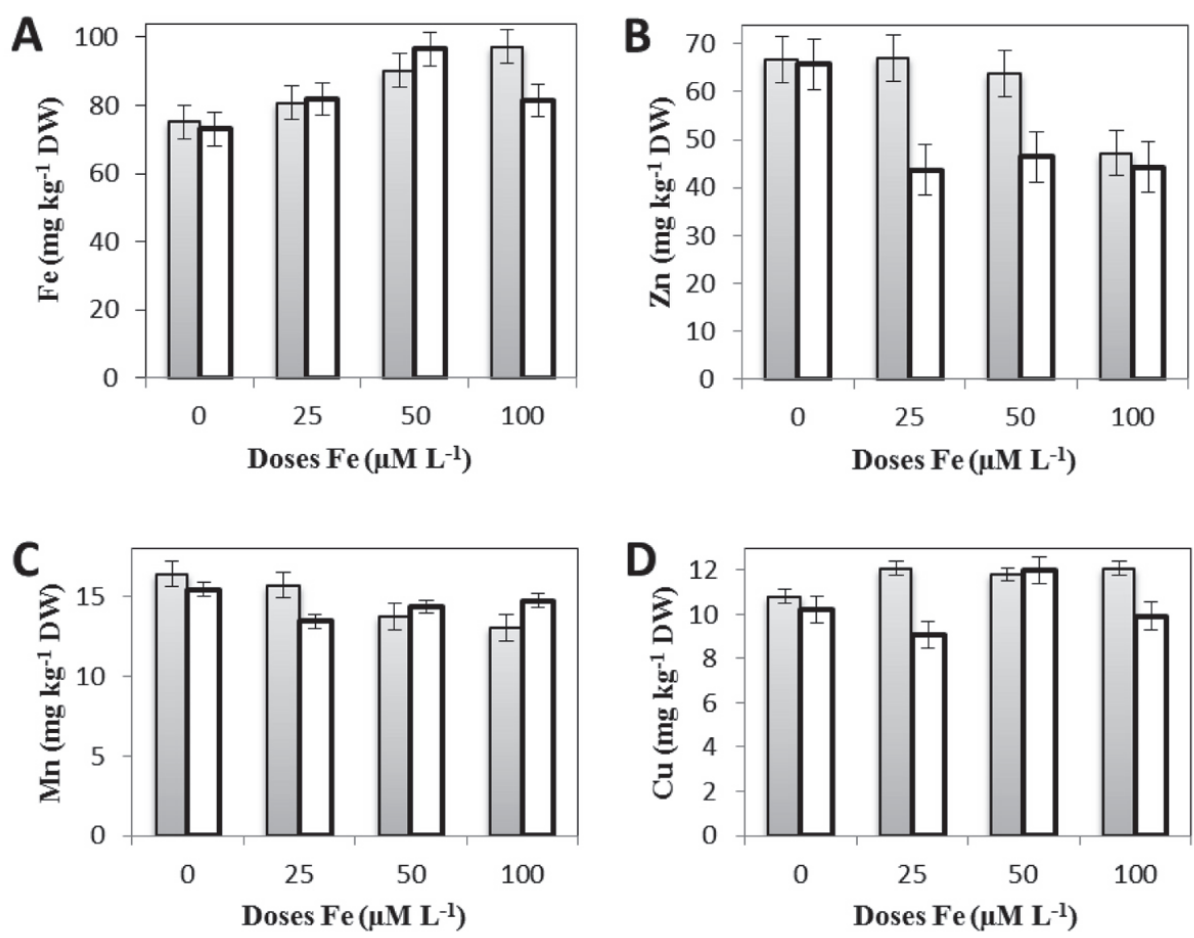

口Ferrous sulfate

DIron chelate

Figure 2. The iron (A), zinc (B), manganese (C) and copper (E) contents in the seed of cowpea bean cultivar De Castilla in response to different application rates of ferrous sulfate and iron chelate. The data are \pm standard error $(n=4)$, and they are significantly different from the initial values at $\mathrm{P}<0.001$ based on the orthogonal contrast test.

In the present study, the concentration of cationic macronutrients in the seed tissue was less pronounced than it was in the results of a study by Espinosa-Moreno et al. (2013), who found that the seed N, P, K, Ca, and $\mathrm{Mg}$ contents were $3.5 \%, 0.35 \%, 1.52 \%, 0.28 \%$, and $0.22 \%$, respectively, with especially pronounced results for $\mathrm{Ca}$ and $\mathrm{K}$. Because of its poor phloem mobility, $\mathrm{Ca}$ is known to be predominantly deposited in the vegetative tissues of maturing plants (Marschner, 2002).

Plants are the principal source of dietary Fe for most of Earth's population, and Fe deficiency can lead to major health problems. In our study, the Fe content had values varying from 73.1 to $97.2 \mathrm{ppm}$, and the highest $\mathrm{Fe}$ content was found in plants treated with $100 \mu \mathrm{M} \mathrm{L}^{-1}$ ferrous sulfate and $50 \mu \mathrm{M} \mathrm{L}^{-1}$ iron chelate, with an increase of $29.4 \%$ and $32.0 \%$, respectively, over the control (Figure 2A). The results reported here demonstrated that agronomic biofortification through fertilization could significantly increase the Fe concentration in cowpea beans. A similar observation was reported previously by Aciksoz et al. (2011), OrtegaBlu and Molina-Roco et al. (2007), and Bilski et al. (2012). However, Aciksoz et al. (2011), noted that one major problem impairing the success of Fe soil or fertilization application is the rapid conversion of 
Fe into unavailable forms when applied to calcareous soils and the poor mobility of $\mathrm{Fe}$ in the phloem, and thus soil Fe fertilization appears to be less effective than foliar Fe fertilization (Welch and Graham, 2005). The $\mathrm{Zn}$ content declined by $20.1 \%$ and $29.2 \%$ in plants treated with 50 and $100 \mu \mathrm{M} \mathrm{L}^{-1}$ ferrous sulfate, and $33.6 \%, 29.3 \%$, and $32.5 \%$ with 25,50 , and $100 \mu \mathrm{M}$ $\mathrm{L}^{-1}$ iron chelate, respectively, over the control (Figure 2B). In this sense, lower macronutrient concentrations (e.g., $\mathrm{P}$ and $\mathrm{N}$ ) in seeds may sometimes be associated with a lower seed $\mathrm{Zn}$ concentration (Rengel, 2002). In comparison with the control, the Mn content declined by $20.7 \%$ and $12.9 \%$ with $100 \mu \mathrm{M} \mathrm{L}^{-1}$ ferrous sulfate and $25 \mu \mathrm{M} \mathrm{L}^{-1}$ iron chelate, respectively (Figure $2 \mathrm{C}$ ). However, the B content increased by $4.2 \%$ with $50 \mu \mathrm{M} \mathrm{L}^{-1}$ ferrous sulfate and by $25.6 \%, 25.6 \%$, and $18.1 \%$ with 25,50 , and $100 \mu \mathrm{M} \mathrm{L}^{-1}$ iron chelate, respectively, over the control (Figure 2D). The acquisition of metal ions, such as Fe, is important for plant survival. Iron has special importance because its ability to change redox states, making it an indispensable cofactor that is responsible for the function of electron transporter chains and catalytic processes (Briat, 2011). However, Fe over accumulation may lead to the overproduction of reactive oxygen species, resulting in cellular damage, necrosis, and, potentially, death. Therefore, the amount of Fe taken up by the roots must be strictly controlled (Ravet et al., 2009). The re-partition of $\mathrm{Fe}$ between the various parts of a plant depends both on the physiological roles that are fulfilled by the metal ion and on the physiological function of the tissues. In this sense, the concentrations of free $\mathrm{Fe}^{2+}$ and $\mathrm{Fe}^{3+}$ in plant tissues are low because $\mathrm{Fe}$ cations are either incorporated into enzyme proteins or complexed with low-molecularweight organic compounds (Briat, 2011).

Studies on wheat plants showed that raising the grain protein concentration increased the storage capacity for Fe and Zn (Cakmak et al., 2010; Kutman et al.,
2010), supporting the idea that the grain capacity for accumulating $\mathrm{Fe}$ is largely influenced by the amount of grain protein (Gomez-Becerra et al., 2010). These results and observations support the suggestion that the seed protein content helped to increase the seed Fe content of plants in this study.

\subsection{The physical characteristics of the seeds and the yield}

Trace elements are also important for the proper development of humans and plants, and they are normally required in small quantities. $\mathrm{Fe}$ is involved as a redox-active metal in photosynthesis, mitochondrial respiration, nitrogen assimilation, hormone biosynthesis, the production and scavenging of reactive oxygen species, osmoprotection, pathogen defense, and as a limiting factor for biomass production (Briat, 2011).

The ranges of the cowpea bean seed dimensions were 7.1 to $8.3 \mathrm{~mm}$ long, 5.3 to $5.9 \mathrm{~mm}$ wide, and 4.1 to 4.8 $\mathrm{mm}$ thick (Table 1), and the 100 seed weights varied from 12.0 to $15.0 \mathrm{~g}$, which was consistent with measurements from the literature (Giami, 2005; Firouzi and Alizadeh, 2012). In the present study, the highest pods per plant, seeds per plant, and seed yield were found in plants treated with $25 \mu \mathrm{M} \mathrm{L}^{-1}$ ferrous sulfate and $100 \mu \mathrm{M} \mathrm{L}^{-1}$ iron chelate, with an increase of $80.0 \%, 48.7 \%$, and $45.9 \%$, respectively over the control, for ferrous sulfate and $13.6 \%, 19.3 \%$, and $4.4 \%$, respectively, for iron chelate over the control (Table 1). This finding exceeded the overall average yield of $13.0 \mathrm{~g}$ per plant obtained by local farmers by $283.8 \%$ and $206.2 \%$ (SIAP, 2013). Our results show a decline of 18.1 and $43.6 \%$ in the seed yield with 50 and 100 $\mu \mathrm{M} \mathrm{L}^{-1}$ ferrous sulfate. This finding may be explained by the results obtained by Hemantaranjan and Garg (1988), who mentioned that increasing the Fe fertilization caused an initial increase in the Triticum aes- 
tivum (L.) yield followed by a decline as the amounts of Fe fertilizer continued to increase.

The results presented here may have important implications for human nutrition. Iron deficiency is a growing public health problem in human populations that is associated with reduced dietary Fe intake (Cakmak et al.,
2010). There is an urgent need to improve the Fe concentrations in food crops to minimize Fe deficiency-related health problems in human populations. According to the results obtained in the present study, fertilizing with ferrous sulfate and iron chelate could improve the Fe concentration and seed yield significantly.

Table 1. The physical characteristics of seed and yield components for the cowpea bean cultivar De Castilla in response to different application rates of ferrous sulfate and iron chelate.

\begin{tabular}{|c|c|c|c|c|c|c|c|c|}
\hline \multirow[t]{2}{*}{ Treatment } & \multirow{2}{*}{$\begin{array}{c}\text { Rates } \\
\left(\mu \mathrm{M} \cdot \mathrm{L}^{-1}\right)\end{array}$} & \multicolumn{3}{|c|}{ Seed dimensions $(\mathrm{mm})^{\mathrm{a}}$} & \multirow{2}{*}{$\begin{array}{c}100 \text { seed weight } \\
(\mathrm{g})^{\mathrm{b}}\end{array}$} & \multirow{2}{*}{$\begin{array}{c}\text { Pods } \\
\text { per plant }\end{array}$} & \multirow{2}{*}{$\begin{array}{c}\text { Seeds } \\
\text { per plant }\end{array}$} & \multirow{2}{*}{$\begin{array}{l}\text { Seed yield } \\
\text { (g per plant) }\end{array}$} \\
\hline & & Length & Width & Thickness & & & & \\
\hline 1. $\mathrm{FeSO}_{4}$ & 0 & $7.7 \pm 0.4$ & $5.7 \pm 0.2$ & $4.8 \pm 0.2$ & $15.0 \pm 1.9$ & $20.0 \pm 4.0$ & $279.0 \pm 88.0$ & $34.2 \pm 6.8$ \\
\hline 2. $\mathrm{FeSO}_{4}$ & 25 & $8.2 \pm 0.4$ & $5.9 \pm 0.1$ & $4.6 \pm 0.2$ & $13.0 \pm 2.6$ & $36.0 \pm 6.0$ & $414.0 \pm 114.0$ & $49.9 \pm 6.7$ \\
\hline 3. $\mathrm{FeSO}_{4}$ & 50 & $7.1 \pm 0.5$ & $5.3 \pm 0.6$ & $4.1 \pm 0.5$ & $14.0 \pm 4.2$ & $20.0 \pm 8.0$ & $241.0 \pm 158.0$ & $28.0 \pm 10.0$ \\
\hline 4. $\mathrm{FeSO}_{4}$ & 100 & $7.7 \pm 0.3$ & $5.3 \pm 0.6$ & $4.3 \pm 0.4$ & $13.0 \pm 2.3$ & $13.0 \pm 7.0$ & $163.0 \pm 63.0$ & $19.3 \pm 9.3$ \\
\hline 5. Fe-EDDHA & 0 & $7.7 \pm 0.4$ & $5.7 \pm 0.2$ & $4.8 \pm 0.2$ & $15.0 \pm 1.9$ & $22.0 \pm 4.0$ & $280.0 \pm 88.0$ & $34.3 \pm 6.8$ \\
\hline 6. Fe-EDDHA & 25 & $7.6 \pm 0.3$ & $5.4 \pm 0.1$ & $4.3 \pm 0.1$ & $12.0 \pm 4.0$ & $25.0 \pm 11.0$ & $334.0 \pm 177.0$ & $35.8 \pm 13.3$ \\
\hline 7. Fe-EDDHA & 50 & $8.3 \pm 0.6$ & $5.7 \pm 0.6$ & $4.7 \pm 0.4$ & $12.0 \pm 2.8$ & $26.0 \pm 7.0$ & $332.0 \pm 47.0$ & $39.8 \pm 5.1$ \\
\hline 8. Fe-EDDHA & 100 & $8.1 \pm 0.5$ & $5.5 \pm 0.5$ & $4.5 \pm 0.3$ & $12.0 \pm 1.2$ & $31.0 \pm 28.0$ & $423.0 \pm 326.0$ & $47.3 \pm 37.6$ \\
\hline \multicolumn{9}{|c|}{ Treatment comparisons (P-values of linear orthogonal contrast) } \\
\hline \multicolumn{2}{|c|}{1 vs $2+3+4$} & 0.333 & 0.652 & 0.194 & 0.144 & 0.885 & 0.441 & 0.518 \\
\hline \multicolumn{2}{|c|}{2 vs $3+4$} & 0.089 & 0.550 & 0.260 & 0.733 & 0.724 & 0.705 & 0.490 \\
\hline \multicolumn{2}{|c|}{3 vs 4} & 0.610 & 0.724 & 0.364 & 0.767 & 0.588 & 0.493 & 0.561 \\
\hline \multicolumn{2}{|c|}{5 vs $6+7+8$} & 0.898 & 0.582 & 0.055 & 0.753 & 0.700 & 0.940 & 0.949 \\
\hline \multicolumn{2}{|c|}{6 vs $7+8$} & $0.027^{\mathrm{C}}$ & 0.049 & 0.100 & 0.670 & 0.034 & 0.078 & 0.029 \\
\hline \multicolumn{2}{|c|}{7 vs 8} & 0.161 & 0.929 & 0.629 & 0.882 & 0.458 & 0.560 & 0.503 \\
\hline
\end{tabular}

\section{Conclusions}

Our experimental results suggest that the mineral seed contents and yields in cowpea plants are most affected by Fe fertilizer applications. Under the experimental conditions, ferrous sulfate at $25 \mu \mathrm{M} \mathrm{L}^{-1}$ and iron chelate at $100 \mu \mathrm{M} \mathrm{L}^{-1}$ could significantly improve the $\mathrm{Fe}$ concentration in cowpea beans and favored the seed yield over that of the control. In addition, the high ferrous sulfate rates caused a dramatic reduction in seed yield. Finally, it would be feasible to implement an $\mathrm{Fe}$ fertilization program in Tabasco to improve the nutritional quality of cowpea bean crops by increasing the $\mathrm{Fe}$ concentrates in the seeds.

\section{Acknowledgments}

This study was financed by the Retención of CONACYT, project No. 203335. In addition, we thank CONACYT for the grant awarded to César MárquezQuiroz. 


\section{References}

Aciksoz, S.B., Yazici, A., Ozturk, L., Cakmak, I. 2011. Biofortification of wheat with iron through soil and foliar application of nitrogen and iron fertilizers. Plant Soil. 349, 215-225.

Alcántar, G.G., Sandoval, V.M., 1999. Manual de análisis químico de tejido vegetal. Publicación Especial 10. Sociedad Mexicana de la Ciencia del Suelo. A. C. Chapingo, México. 156 pp.

Amarakoon, D., Thavarajah, D., McPhee, K., Thavarajah, P. 2012. Iron-, zinc-, and magnesiumrich field peas (Pisum sativum L.) with naturally low phytic acid: A potential food-based solution to global micronutrient malnutrition. J Food Compos Anal. 27, 8-13.

AOAC, 2002. (Association of Official Analytical Chemists). Official Methods of Analysis of the AOAC. Washington, D.C. USA. In: Horwitz, W. (Ed.). The Association of Official Analytical Chemists.

Bilski, J., Jacob, D., Soumaila, F., Kraft, C., Farnsworth, A. 2012. Agronomic biofortification of cereal crop plants with $\mathrm{Fe}, \mathrm{Z}$, and Se, by the utilization of coal fly ash as plant growth media. Adv Biores. 3, 130-136.

Blair, M.W. 2013. Mineral Biofortification Strategies for Food Staples: The Example of Common Bean. J Agr Food Chem. 61, 8287-8294.

Briat, J.F. 2011. Iron Nutrition and Implications for Biomass Production and the Nutritional Quality of Plant Products. The Molecular and Physiological Basis of Nutrient Use Efficiency in Crops. Wiley-Blackwell, pp. 311-334.

Cakmak, I., Pfeiffer, W.H., McClafferty, B. 2010. Biofortification of Durum Wheat with Zinc and Iron. Cereal Chem. 87, 10-20.
Carvalho, A.F.U., de Sousa, N.M., Farias, D.F., da Rocha-Bezerra, L.C.B., da Silva, R.M.P., Viana, M.P., Gouveia, S.T., Sampaio, S.S., de Sousa, M.B., de Lima, G.P.G., de Morais, S.M., Barros, C.C., Filho, F.R.F. 2012. Nutritional ranking of 30 Brazilian genotypes of cowpeas including determination of antioxidant capacity and vitamins. $\mathrm{J}$ Food Compos Anal. 26, 81-88.

Espinosa-Moreno, J., Centurión-Hidalgo, D., Solano, M.L., Lagunes-Gálvez, L.M. 2013. Las leguminosas de grano. P 183-190. In: Velázquez Martínez, J.R., López Hernández, E., García Alamilla, P. (Eds.), Desarrollo Científico y Tecnológico de los Recursos Alimentarios en el Estado de Tabasco. Universidad Juárez Autónoma de Tabasco.

Firouzi, S., Alizadeh, M. 2012. Effect of Moisture Content on Selected Physical Characteristics of Cowpea Seed (Vigna unguiculata L. Walp). Ann Biol Res. 3, 3583-3590.

Giami, S.Y. 2005. Compositional and nutritional properties of selected newly developed lines of cowpea (Vigna unguiculata L.Walp). J Food Compos Anal. 18, 665-673.

Gomez-Becerra, H.F., Erdem, H., Yazici, A., Tutus, Y., Torun, B., Ozturk, L., Cakmak, I. 2010. Grain concentrations of protein and mineral nutrients in a large collection of spelt wheat grown under different environments. J Cereal Sci. 52, 342-349.

Gómez-Galera, S., Rojas, E., Sudhakar, D., Zhu, C., Pelacho, A., Capell, T., Christou, P. 2010. Critical evaluation of strategies for mineral fortification of staple food crops. Transgenic Res. 19, 165-180.

Hemantaranjan, A., Garg, O.K. 1988. Iron and zinc fertilization with reference to the grain quality of Triticum aestivum L. J Plant Nutr. 11, 1439-1450.

Hoagland, D.R., Arnon, D.I. 1950. The Water-culture Method for Growing Plants Without Soil. College of Agriculture, University of California in Berkeley, Calif. pp 32. 
Katoch, R. 2013. Nutritional Potential of Rice Bean (Vigna Umbellata): An Underutilized Legume. J Food Sci. 78, C8-C16.

Kutman, U.B., Yildiz, B., Ozturk, L., Cakmak, I. 2010. Biofortification of Durum Wheat with Zinc Through Soil and Foliar Applications of Nitrogen. Cereal Chem. 87, 1-9.

Mao, H., Wang, J., Wang, Z., Zan, Y., Lyons, G., Zou, C. 2014. Using agronomic biofortification to boost zinc, selenium, and iodine concentrations of food crops grown on the loess plateau in China. $\mathrm{J}$ Soil Sci Plant Nut. 14, 459-470.

Marschner, H. 2002. Mineral nutrition of higher plants (Second Edition). Academic Press, London. pp 889.

Ortega-Blu, R., Molina-Roco, M. 2007. Comparison between sulfates and chelated compounds as sources of zinc and iron in calcareous soils. Agrociencia-Mexico. 41, 491-502.

Ravet, K., Touraine, B., Boucherez, J., Briat, J.-F., Gaymard, F., Cellier, F. 2009. Ferritins control interaction between iron homeostasis and oxidative stress in Arabidopsis. Plant J. 57, 400-412.

Rengel, Z. 2002. Agronomic approaches to increasing zinc concentration in staple food crops. In: Impacts of agriculture on human health and nutrition. Cakmak I, Welch R. M (Eds.). UNESCO, EOLSS (http://www.eolss.net).
Sadeghzadeh, B., Rengel, Z. 2013. A review of zinc nutrition and plant breeding. J Soil Sci Plant Nut. 13, 905-927.

SAS Institute, I. 2009. SAS/STAT 9.2 User's Guide. Second Edition. Cary, NC, USA. SAS Institute Inc. pp 7869.

SIAP, 2013. (Servicio de Información Agroalimentaria y Pesquera). Anuario Estadístico de la Producción Agrícola. Cierre de la producción agricola por estado de frijol pelón. [Date of consulting: july 18, 2014] Available in: http://www.siap.gob. $\mathrm{mx} /$ cierre-de-la-produccion-agricola-por-estado/.

Welch, R.M., Graham, R.D. 2004. Breeding for micronutrients in staple food crops from a human nutrition perspective. J Exp Bot. 55, 353-364.

Welch, R.M., Graham, R.D. 2005. Agriculture: the real nexus for enhancing bioavailable micronutrients in food crops. J Trace Elem Med Bio. 18, 299-307.

White, P.J., Broadley, M.R. 2005. Biofortifying crops with essential mineral elements. Trends in Plant Sci. 10, 586-593.

Wolf, B. 1982. A comprehensive system of leaf analyses and its use for diagnosing crop nutrient status. Commun Soil Sci Plan. 13, 1035-1059. 